\title{
Iceland's External Affairs from 1400 to the Reformation: Anglo-German Economic and Societal Shelter in a Danish Political Vacuum
}

\author{
Baldur Pórhallsson, Professor of Political Science, University of Iceland, \\ and Porsteinn Kristinsson, Research Assistant, University of Iceland
}

\begin{abstract}
The paper applies the assumption that small states/entities need economic and political shelter in order to prosper, to the case of Iceland in the period from 1400 to the Reformation in the mid $-16^{\text {th }}$ century. Also, it applies the findings from the first paper in this 'hexalogy' (a six-paper series) on Iceland's external relations in a historical context, i.e. that Iceland enjoyed societal shelter in the Middle Ages, to this period. The aim is both to analyse whether or not Icelanders enjoyed economic, political and societal cover from their engagements with the Danes, English and Germans and to evaluate the validity of the 'shelter theory'. The paper argues that Iceland enjoyed considerable economic and societal shelter from its encounters with English and German merchants and fishermen in a period in which Danish political cover was formally in place but was not effective in practice. Moreover, the paper claims that the shelter theory, and small-state studies in general, need to take notice of the importance of social communication with the outside world for a small entity/state. Also, the Danish political vacuum in our late Medieval Period provided the islanders with economic opportunities and social engagements with the wider world. This was at the cost of continued domestic clashes between the islanders themselves, on the one hand, and between them and 'outsiders' on the other. Our findings indicate that in the case of Iceland there might be a trade-off between the
\end{abstract}

Icelandic Review of Politics and Administration Vol. 9, Issue 1 (113-137)

(C) 2013 Contact: Baldur pórhallsson, baldurt@hi.is

Article first published online June 26th 2013 on http://www.irpa.is

Publisher: Institute of Public Administration and Politics, Gimli, Sæmundargötu 1, 101 Reykjavík, Iceland

Stjórnmál \& stjórnsýsla 1. tbl. 9. árg. 2013 (113-137) Fræđigreinar

(C) 2013 Tengiliður: Baldur Pórhallsson, baldurt@hi.is

Vefbirting 26. júní 2013 - Birtist á vefnum http://www.stjornmalogstjornsysla.is

Útgefandi: Stofnun stjórnsýslufræđa og stjórnmála, Gimli, Sæmundargötu 1, 101 Reykjavík

DOI: http://dx.doi.org/10.13177/irpa.a.2013.9.1.6

This work is licensed under a Creative Commons Attribution 3.0 License. 
benefits of strict political cover by a single external actor, and the economic and societal opportunities accompanied by a lack of political affiliations.

Keywords: Iceland, small states, international relations, shelter, economy, culture, politics, late Middle Ages.

\section{Introduction}

The aim of this paper is to examine whether Iceland's external relations provided its inhabitants with political, economic and societal shelter in the period extending from the beginning of the $15^{\text {th }}$ century to the Reformation in the mid- $16^{\text {th }}$ century. This is the period often referred to as consisting of 'the English Age' and 'the German Age' in Icelandic historiography because of the extent of maritime contact between those countries and Iceland at the time. The period was preceded by 'the Norwegian Age' in which Iceland's external relations were almost exclusively conducted through the Norwegian kingdom and would be succeeded by 'the period of Danish rule' in which Iceland, again, narrowed its horizon and largely confined its external relations to Denmark. The English and German Ages were therefore a time in which Iceland's external relations were quite complex and diverse compared to the other eras.

This is the second paper $^{1}$ in a 'hexalogy': six papers ${ }^{2}$ dedicated to the study of Iceland's external relations from the Settlement to the present. The aim is twofold. Firstly, it is to locate Iceland in the framework of small-state theory by examining whether Iceland has enjoyed external shelter from other states/entities during its history. Secondly, Iceland's engagement with the outside world is used as a case study in order to evaluate the theory that small states/entities need external shelter to thrive, economically and politically.

The literature on small states in international relations has generally considered small states to be in need of a protecting power or an alliance in order to prosper (see, e.g., Thorhallsson 2011). There are two main reasons for this. Firstly, small states are more dependent on foreign trade than large states because of the small size of their domestic market and relatively concentrated production. In order to achieve economies of scale, they tend to specialise in producing very few products - the bulk of which need to be exported - and in turn need to import many products that larger states can produce domestically (Katzenstein 1985). Secondly, small states have more limited means to defend themselves compared with their larger neighbours (Vital 1967, 152-154). They therefore often seek security from larger states or through multilateral alliances (Rothstein 1968, 36-37).

Hence, small states need protection in order to withstand stress due to their more limited resources as compared to larger states (Vital 1967). According to Baldur Thorhallsson (2011), the importance of shelter is related to three interrelated features: reduction of risk in the face of a possible crisis event; help in absorbing shocks during a crisis situation; and assistance in dealing with the aftermath of the crisis. The shelter theory distinguishes between economic and political shelter. Political shelter takes the form of direct and visible diplomatic or military backing, and other strategic coverage, in any 
given time of need by another state or an international organization, and/or organizational rules and norms. Economic shelter consists of direct and/or indirect economic assistance such as that provided by a common market.

Importantly, the first paper in the series (Baldur Pórhallsson 2012) concluded that Iceland's external shelter consisted of three elements: economic shelter, political shelter and societal shelter. The traditional small-state literature has usually only addressed the importance of economic and political shelter. The additional inclusion of societal shelter is therefore a supplement to small-state theory - an innovation that will be pursued further in this paper. This is in line with Rokkan and Urwin's (1983) historical account of the importance of centre-periphery relations in their attempts to explain state-building in Western Europe. They combine political, economical and cultural features in order to explain state-building and argue that cultural transactions, in terms of transfer of messages, norms, lifestyles, ideologies, myths and ritual systems, are important in constructing the centre-periphery relations. For instance, they claim that long distances make cultural communications more difficult and increase the likelihood of a separate identity.

To be clear, it is not being suggested that relations between small and large entities are always favourable for the smaller entity, and certainly not that the larger entity acts out of some kind of altruism. For instance, Vital $(1967,79)$ argues that 'where the quest for protection and insurance is successful a price must normally be paid in terms of sacrifice of autonomy in the control of national resources and loss of freedom of political maneuver and choice'. Hence, protection often comes at a certain cost. For instance, the political and economic shelter of the European Union involves adopting the protector's rules and norms (Bailes \& Thorhallsson 2013; Katzenstein 1997). Also, international financial institutions' aid is often given with preconditions regarding states' domestic policies, and NATO cover may carry considerable costs related to its application (Bailes \& Thorhallsson 2013). One state's dominance over another may include severe economic, political and societal costs, as is shown by numerous historical examples. The ultimate price a small state/entity would pay for cover would be for it to become part of the protector's territory without any means of controlling its own affairs.

We will define shelter as those external relations that are favourable to the small entity - in our case Iceland - according to the shelter theory presented above. Of course there were always external relations that were harmful to Icelanders over the years, and these will be identified as well. The validity of the theory then depends on whether the benefits of external relations are greater than the costs and whether the relations were actively sought after by Icelanders themselves.

However, there is another factor that may complicate the theory. Iceland, like other societies, was divided into different groups that sometimes had conflicting interests. In a relatively stable society, the sudden influx of foreign influence can upset the prevailing social structure, providing positive opportunities for certain segments of the population while alienating others. Such seems to have been the case during the period under study as economic opportunities for the general public engendered by the presence of foreigners undermined the position of the farming elite in the agrarian economic structure. 


\section{STJÓRNSÝSLA}

The 'shelter theory' therefore needs to be sensitive to the way in which external relations can have an impact on domestic conflicts of interest. The historical record - especially from the period we are dealing with - inevitably reflects the viewpoint of the ruling elite and should be interpreted accordingly. What the ruling elite sees as foreign threats might well be interpreted as shelter for the ordinary man and vice versa.

It should be kept in mind that Iceland was not a 'state' in the modern sense during most of the 11 centuries that the island has been inhabited. Nor has the overall structure of world politics been the same for the last millennium (see Linklater 2008). In the Middle Ages, international politics in Europe were characterised by a complex structure of overlapping and competing authorities of subnational, transnational and supranational actors, in addition to the various forms of states at the time (Armstrong 2008, 38, 4244; Tilly 1990, 5, 38-40). Iceland was part of this 'complex medieval order', being under the Norwegian (from the making of the Old Covenant in 1262), and later the Danish, crown (with the establishment of the Kalmar Union in 1397, which formally merged the kingdoms of Norway, Denmark and Sweden), as well as coming under the religious authority of the Pope. In addition, domestic authority on the island was often divided between powerful sheriffs who wielded various degrees of autonomy in their respective regions.

Any theory that seeks to address such a long and diverse period must be sensitive to the changing nature of international relations over time. However, the theoretical work in the small-state literature discussed in the previous paragraphs mainly addresses the modern period of the Westphalian era. The subject of the theory is small states and their place in an international community of states. One might therefore ask whether the theory is appropriate at all for analysing the period under study in this paper, given the different nature of world politics at the time. When modern theories are applied to the past, the danger is that social constructions of the modern world (such as nation states) will be projected onto the past, causing a distorted reading of history. For example, when the theory that small states need external shelter is applied to the Middle Ages, it has already been implicitly asserted that states, small and large, were the principal actors in world politics at the time. In fact, this is the same criticism that has been directed against Realism's treatment of the past, i.e., its attempt to force a statist understanding of world politics onto past international structures, regardless of political realities (Linklater 2009, 145). On the other hand, Realists argue that their theory applies to the past as well as to the present and continue to apply it to cases from the ancient world (Sheehan 2005).

In order to avoid such an anachronistic reading of history, the 'shelter theory' must be adapted to the international environment at any given time in history under study. Indeed, the theory must be viewed, not strictly as a state-centric theory, but as a theory about the relations between small entities/societies/polities and the wider world. In other words, the theory must be sufficiently broad to span a whole millennium, while at the same time being specific enough to have something meaningful to say about the nature of world politics. Constructing such a grand theory has both advantages and disadvantages. The main disadvantage is that the theory must be quite general and cannot deal 


\section{STJÓRNMÁL \& \\ STJÓRNSÝSLA}

with the more nuanced aspects of world politics at any given time. It seeks to discern broad patterns in the history of world politics rather than to delve into the intricacies of individual historical events. However, the general nature of grand narratives may also be an asset. If a theory needs to be applicable to a wide range of historical situations, it is more likely that it is actually pointing to an underlying mechanism of world politics. Theories that apply exclusively to the present have the danger of becoming little more than complex descriptions of current events and become useless as soon as anything changes. Therefore, the attempt to apply small-state theory to Iceland's millennial history is a challenge, but also an opportunity to broaden the theory's validity and offer new insights into its operations.

A major difference between the period under study in this article and the shelter provided by the Norwegian Sea Power addressed in the first article, is the disjunction of political, economic and social relations during much of the English and German Ages. Iceland's relations with the outside world were fragmented among multiple external actors, often with conflicting agendas and operating in different social spheres. The early $15^{\text {th }}$ century saw the arrival in Iceland of Englishmen who soon came to dominate commerce on the island and would do so for much of the century. This provided the islanders with important economic and societal shelter in the form of transportation, beneficial terms of trade, new goods and economic opportunities for the general public. The Danish crown retained nominal authority over Iceland due to its control of the Sound (the waterway between Scania and Zealand connecting the North Sea and the Baltic) but had little capacity to enforce its will on the island in practice. As a consequence, the Danish crown did not provide Iceland with political cover apart from preventing the island from slipping from the Scandinavian domain and falling under English rule.

During the last decades of the $15^{\text {th }}$ century, German merchants became significant economic actors and shelter providers in Iceland and worked closely with the Danish crown in order to curtail the influence of the English. But again, the political power of the Danish crown and the economic muscle of 'outsiders', this time the Germans, led to tensions. The Danish authorities soon tried to reduce their dependence on the Germans and replace them by fostering the establishment of Danish trade in Iceland. In the middle of the $16^{\text {th }}$ century, the domestic Danish administration was substantially strengthened by the Reformation but merchants from outside the kingdom would play an important role in Iceland's foreign trade throughout the $16^{\text {th }}$ century and well into the $17^{\text {th }}$.

In the period under study, Icelanders enjoyed societal cover through their close engagement with the Catholic Church and encounters with the English and the Germans. Thus, Iceland was remarkably well connected to the outside world despite its peripheral geographical location. Iceland was on the political, economic and cultural map of Western Europe: events on the island led to conflicts between competing European powers and its extensive overseas relations kept it in close contact with European norms - societal norms - of the period. Hence, the small-state literature needs to acknowledge the importance of social communication for small entities, cultural relations being as valu- 


\section{STJÓRNSÝSLA}

able as economic and political relations for small entities. For Icelanders themselves, the intensity and the complexity of their external relations in our period under study were unprecedented. They had a profound influence on Icelandic society, putting significant strains on prevailing economic and political structures and bringing social and cultural influences from other parts of Europe. The response of Icelanders to these challenges was at times conservative, but sometimes they were also quick to spot new opportunities and grasp them.

The remainder of the paper starts by exploring Iceland's external economic relations before turning attention to a discussion of Iceland's external political and societal shelter during the period under study. The conclusion offers a summary of the main findings regarding Iceland's external cover and further suggestions on modifications of the shelter theory.

\section{Economic shelter}

In the $14^{\text {th }}$ century the Norwegian kingdom slowly started to disintegrate. German Hansa merchants took control of most Norwegian foreign trade and political power shifted southwards, turning Norway into a peripheral zone in a new Scandinavian kingdom, centred on Denmark, which came into being as the century drew to a close (Porsteinsson \& Grímsdóttir 1989, 217-234 \& 1990, 15). These developments were accompanied by a significant decline in Norwegian shipping contact with Iceland and thus a breakdown of the economic, political and societal shelter hitherto provided by Norway.

However, the void left by the Norwegian sea power was soon filled by English seamen, who started sailing to Iceland sometime around the beginning of the $15^{\text {th }}$ century (Porsteinsson 1970, 23-31). While the exact year is uncertain, licences to trade and customs accounts in England show that already in 1408-09 there was major direct contact between England and Iceland both for fisheries and trade purposes (Childs 1995, 12). In 1414 the Danish king, Erik af Pommern, sent a letter to Iceland forbidding trade with foreigners and the following year he sent a delegation to the English king complaining about the conduct of English fishermen in Iceland (Karlsson 2009, 287). However, the ban had little effect since the crown had no means of enforcing it in Iceland (Porsteinsson 1965, 32).

Indeed, Icelanders made no secret of their trade with the English and presented their arguments for doing so in a salutary letter to the king in 1419. The letter pointed out that the king had not ensured the arrival of six ships each year from Norway, as stipulated by the Old Covenant, and that Iceland had suffered greatly as a result. Icelanders had therefore traded with those foreigners who had come in peace (Karlsson 2009, 287). The letter went on to ask the king how the issue should be solved and how Icelandic foreign trade should be handled in the future (Dorsteinsson \& Grímsdóttir 1990, 27-28). The same year, the governor of Iceland gave two Englishmen permission to trade with Iceland and fish in Icelandic waters for one year (Dorsteinsson 1970, 52).

Although the king's authority was not challenged explicitly, it is clear that Iceland's submission was not unconditional. Iceland decided unilaterally to defy the king's ban on 
foreign trade on the grounds that the king himself had not kept his part of the agreement. In fact the letter can be interpreted as a clear statement that Iceland would not respect the king's ban on foreign trade under the current circumstances and requested that the king would find a better solution. Stripped of its royal discourse, the correspondence looks more like negotiations between two parties than total submission on Iceland's part. This supports the argument that in making the Old Covenant, Iceland had been looking for shelter in the Norwegian kingdom rather than the view that Iceland was 'annexed' by a foreign power against its will. Icelanders' obedience to the king was conditional on the king's provision of shelter, such as regular shipping contact with the island. When that shelter broke down around the turn of the century, Icelanders were both willing and able to defy the authority of the king and look for economic shelter elsewhere - this time in commerce with English merchants.

According to the historian Björn Dorsteinsson, the period from 1426 to 1448 was a time of 'English predominance' in Iceland (Dorsteinsson 1970, 94-163). English merchants had better ships than their competitors and they offered higher prices. They paid 70 per cent more for Icelandic stockfish than the Norwegian merchants from Bergen (Dorsteinsson 1976, 11). It is therefore not surprising that Icelanders were willing to defy the king's ban on foreign trade and, in fact, it is likely that even the king's representatives in Iceland did business with the English merchants (Dorsteinsson \& Grímsdóttir 1990, 30). The Icelandic bishoprics of Hólar and Skálholt used English ships to secure supplies and trade (Childs 1995, 14-19). Moreover, some of the bishops seem to have looked at their appointments as a business opportunity and engaged in considerable external trade (Carus-Wilson 1954, 123-124; Childs 1995, 14-19). Furthermore, Bergen was attacked by German pirates in 1428 and the same year there were clashes at sea between Norwegian merchants and Englishmen. This weakened the crown's defences and made it all the more difficult to maintain stable shipping contact between Norway and Iceland. English merchants therefore had a near monopoly on Icelandic trade relations in the period (Dorsteinsson \& Grímsdóttir 1990, 31-32) and Icelandic governors made trade easier by designating market areas. On the other hand, the English found the Icelandic market very underdeveloped by Western European standards, small and sparsely populated, with no towns. Moreover, the harsh weather conditions made life difficult, and sometimes risky, for the sailors (Childs 1995, 13-19).

Our main question is whether this constituted economic shelter. Firstly, there is nothing to suggest that Icelanders themselves initiated their contact with the English. The beginning of English maritime contact with Iceland has mainly been attributed to exogenous factors, such as technological advancements in shipbuilding in western Europe, poor fish catches in English waters and a difficult situation for English merchants in Bergen (Dorsteinsson 1970, 24-30; Dorsteinsson \& Grímsdóttir 1990, 15-17; Porláksson 2001, 275). However, Icelanders were far from being passive recipients in the relationship. They soon realised the potential in English commerce and were quick to abandon their sole reliance on Norway's faltering sea power. Iceland also tried to regulate its relationship with England from the outset. In the previously mentioned letter to the king, 


\section{STJÓRNSÝSLA}

it is stated that Icelanders had traded with those foreigners who had come in peace, but that those who had caused unrest had been punished (Karlsson 2009, 287). Early on, Iceland also seems to have decided that it was in favour of English commerce in Iceland while being hostile to those Englishmen who only came to fish. Björn Dorsteinsson $(1976,12)$ points out that Icelanders made a clear distinction between merchants, who generally had peaceful relations with the locals, and fishermen, who often came on shore only to pillage. As a result, most English ships took at least some merchandise to Iceland and were 'allowed' to fish in return.

Perhaps the strongest argument for classifying Iceland's relations with English merchants as economic shelter is the access it granted for Icelandic stockfish on foreign markets and the transportation needed to conduct the trade, as is shown in in Figure 1. Such access should not be taken for granted, as it required a considerable amount of maritime contact with Iceland on relatively large ships and such transportation had long been in shorter supply than Iceland found necessary (Porsteinsson 1964, 4). The 'English-Icelandic' sailing season, which is well documented in English records, lasted from April/May until August/September, although occasionally ships would return to England as early as June or as late as October. Merchants and ships from all round England would sail to Iceland though the main active ports were Hull, Bristol and London. In

Figure 1. Iceland's economic shelter: Market access provided by English and German fishermen and merchants from the $15^{\text {th }}$ to the mid-16 ${ }^{\text {th }}$ century

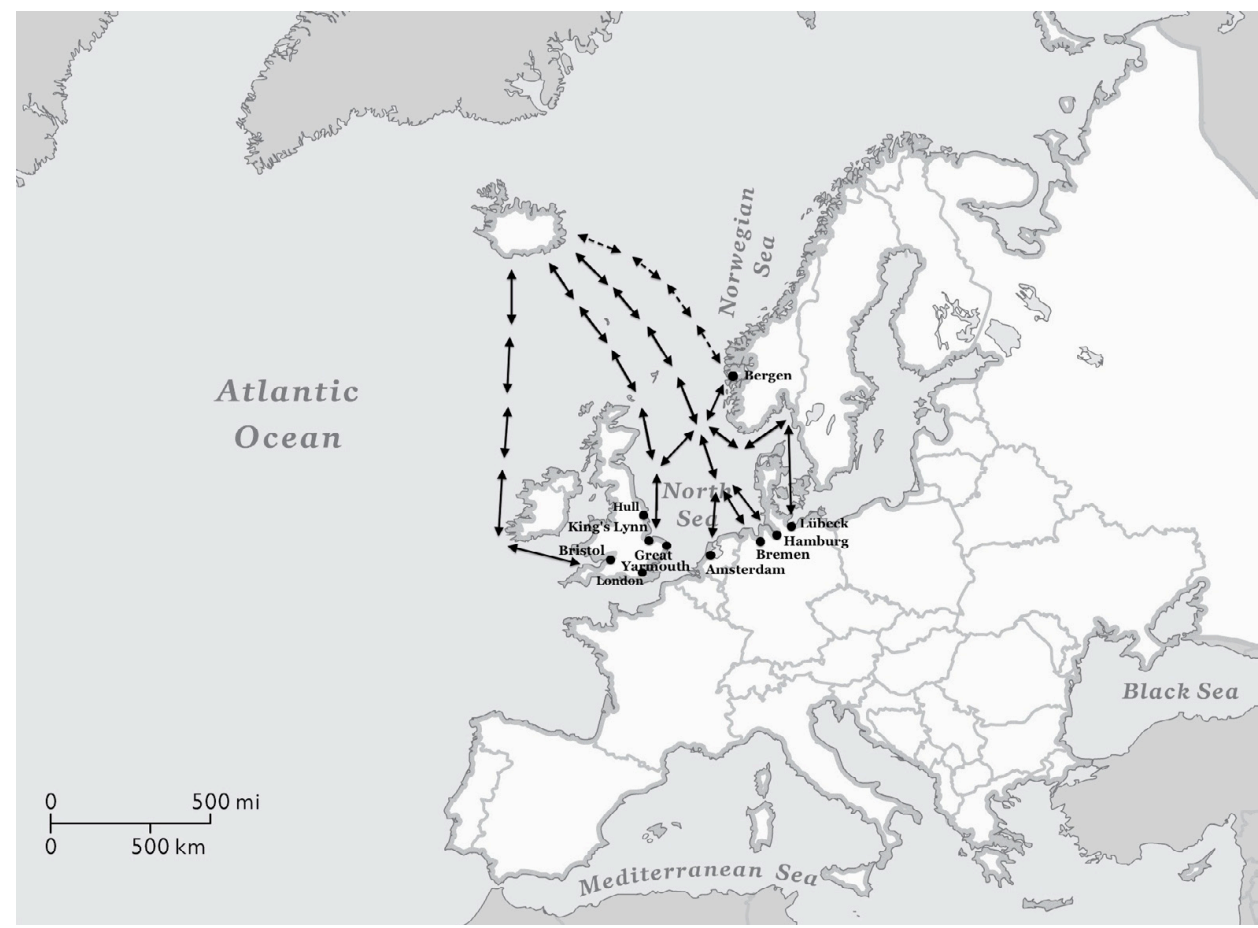


the beginning, ships from Bristol were prominent in the trade but Hull provided more active merchants and ships for the Icelandic trade than Bristol from the mid $15^{\text {th }}$ century - according to licences and customs accounts. The merchants' destination, when specified, was usually the Westman Islands and Hafnarfjordur (Childs 1995, 11-17). 'The trade became regular, reasonably safe, and the same ships, masters, and merchants can be traced going over and over again' (Childs 1995, 13). Iceland became a part of the English merchant shipping system i.e. by the mid-15th century, some vessels would fit into the sailing year the summer Icelandic voyage, the autumn voyage to Bordeaux and one other cruise, possibly to Spain, the Baltic or the Low Countries (Childs 1995, 13). The arrival of English merchants, who were willing to buy large quantities of Icelandic stockfish for a good price, was therefore very important for Iceland, which was becoming an increasingly marginal entity in the Nordic world around the beginning of the 15th century. Iceland had actually become an outpost in northwestern Europe; maritime contact with Greenland had stopped and the king's residence was moved, first to Oslo and later to Copenhagen (Karlsson 2000, 100-104).

Considering Helgi Skúli Kjartansson's (1996) observations about the importance of transportation costs, it seems that the beginning of Icelandic stockfish exports must at least partly be explained by advancements in shipbuilding. Before the $14^{\text {th }}$ century, Iceland's comparative advantage in stockfish production could not be exploited because high transportation costs largely inhibited trade in other than relatively expensive goods, such as processed wool. The emergence of larger ships, capable of carrying larger quantities, therefore made the export of Icelandic stockfish economically viable for the first time. Furthermore, this seems to be consistent with the findings of Helgi Dorláksson (1991, 399-401), who does not believe that falling demand for Icelandic vadmál in Europe explains the origins of Icelandic stockfish exports, as has often been claimed. $\mathrm{He}$ points out that the beginning of stockfish exports were accompanied by an increase in the overall amount of shipping to Iceland and that these exports did not necessarily result in a decrease in the absolute volume of vadmál exports. In other words, stockfish did not replace vadmál as Iceland's main export product because of changing demand on foreign markets - it was simply added to the list of Icelandic exports due to the availability of adequate transport.

Importantly, Helgi Dorláksson (2001) also argues that Icelandic stockfish exports in the $14^{\text {th }}$ century mainly ended up in England after going through Bergen. This is contrary to some older accounts, which assume that the stockfish was resold to Hansa merchants (Porsteinsson 1965, 14 \& 1970, 36; Böðvarsson 1976, 14-15). He points out that although German Hansa merchants were influential in Bergen, they seem to have preferred Norwegian stockfish, which was processed differently. English merchants were thus the main purchasers of Icelandic stockfish from the beginning. This would help explain the decrease in Norwegian shipping to Iceland around the turn of the $14^{\text {th }}$ century, as this was a time when English merchants were largely expelled from Bergen by the Germans. Norwegians had little reason to carry Icelandic stockfish to Bergen if there were no Englishmen there to buy it. Furthermore, Helgi Porláksson's account also 


\section{STJÓRNSÝSLA}

provides an explanation of why English merchants started sailing directly to Iceland at the time that they did: they had been expelled from Bergen so they went to Iceland themselves to buy the stockfish.

If this account is correct, it points to a somewhat more continuous narrative of Iceland's external relations than is often allowed for in Icelandic historiography. English merchants did not just 'happen' to come to Iceland at the time that Norwegian shipping broke down; their sailing to Iceland was directly linked to that breakdown. The economic shelter provided by English commerce in the $15^{\text {th }}$ century thus had antecedents in the $14^{\text {th }}$ century when Norwegian merchants from Bergen acted as middlemen in an already established stockfish trade between Iceland and England. Thus, the direct sailings of English ships to Iceland was, in effect, an example of a commercial enterprise cutting out the middlemen in order to maximise profits (Childs 1995, 12). Furthermore, the beginning of direct maritime contact between England and Iceland meant that Icelanders benefitted more from the trade than before (Karlsson 2009, 284) and for the first time acquired various products that they bought from the English merchants (Dorsteinsson 1970, 36).

In the first half of the $15^{\text {th }}$ century, only occasional ships arrived from the European mainland. The first German ship that is thought to have sailed directly to Iceland was in 1431 or 1432 (Karlsson 2009, 296-298). However, this changed in the 1470s when German merchants started sailing to Iceland in much greater numbers (Böðvarsson 1976, 35). The reasons behind this were largely political - and will be addressed in the following section - but from the economic aspect, it meant that England's de facto monopoly of the Icelandic stockfish trade was over. As the century drew to a close, commerce in Iceland became ever more lively, with merchant ships arriving from a number of German cities and also from Amsterdam, in addition to the traditional sailings from England and Bergen (see Figure 1) (Dorsteinsson 1970, 222-228).

An important difference between the Germans and the English is that the Germans came to Iceland first and foremost to conduct trade with the locals. However, most of the English ships came to Iceland to fish, as well as to trade (Böðvarsson 1976, 41). The Germans soon took control of many of the main trading harbours, arriving as they did on large trading vessels, while the smaller and more scattered fishing fleet of the English continued to prevail in trade with the more remote and inaccessible fjords around the island (Porsteinsson 1970, 239). It can therefore be argued that both occupied an important place in the Icelandic economy: the Germans providing large-scale trade in locally-produced stockfish in the main harbours, while the English indirectly connected some of Iceland's remote places to the outside world through their fishing.

Although English and German merchants competed for their shares of the Icelandic market, it seems that the Germans sold most of their Icelandic stockfish purchases in England on their way home. They probably brought merchandise from the mainland to exchange for fish in Iceland (Böðvarsson 1976, 37; Karlsson 2009, 299). This was the general pattern of the German trade in the last decades of the $15^{\text {th }}$ century. It has been suggested that opposition from Hansa merchants in Bergen was the reason why 
Icelandic stockfish was not sold on the mainland, i.e. in order to prevent competition with fish from Bergen (Porsteinsson \& Grímsdóttir 1990, 111-112). While this may have been important, it has also been pointed out that a difference in taste preference may have mattered. Consumers on the European mainland considered the Icelandic stockfish too firm and preferred the softer Norwegian fish (Dorláksson 2001, 277). Whatever the reason may be, it is clear that around the turn of the century all of this changed. In about 1500, German and Dutch merchants began to sail directly from Iceland to the mainland with shiploads of Icelandic stockfish (see Figure 1) (Böðvarsson 1976, 51-52; Dorsteinsson \& Jónsson 1991, 173). Apparently the Germans had found a new way to process Icelandic stockfish, making it softer and even preferable to the Norwegian product (Porláksson 2001, 277).

This development engendered strong opposition from Hansa merchants who were involved in the Bergen trade. They complained that Icelandic stockfish was much cheaper and that there were no buyers left for the stockfish from Bergen (Porsteinsson \& Grímsdóttir 1990, 112-113). Numerous attempts were made to stop the import of Icelandic stockfish to the European mainland. The Danish king, acting on behalf of Hansa merchants in Bergen, tried to ban the trade, and similar resolutions were passed at Hanseatic assemblies, but to no avail (Böðvarsson 1976, 52-56). The Icelandic trade was far too profitable to be abandoned, and in any case the unity of the Hanseatic cities was rapidly waning for a number of reasons. The interests of Lübeck - the principal city in the Bergen trade - were increasingly at odds with those of other Hanseatic cities, particularly those in the western part of the region such as Hamburg and Bremen (Gade 1951, 104-110). Danish success in hindering trade would have resulted in considerable economic cost for Icelanders. Accordingly, economic shelter was not included in the transfer of royal power from Norway to Denmark. On the other hand, remoteness and the limited means available to the king to impose his will on the island and sailors around its coast prevented him from having his way, as is discussed below.

For Iceland, the arrival of German merchants in Iceland was a welcome development. It increased the overall volume of shipping to Iceland and therefore caused growing competition for Icelandic stockfish. The Germans gained the upper hand in this competition and offered Icelanders better terms of trade (Porsteinsson \& Grímsdóttir 1990, 112-113). One by one, the main trading harbours in Iceland were taken over by the Germans (Agnarsdóttir 1993, 166). This was the 'German Age' in Iceland.

On the other hand, English fishermen continued their activities and Jones (2000, 105) argues that the main expansion in English fishing around Iceland took place in the years 1490 to 1530 . This may be related to an agreement between Denmark and England in 1490, allowing Englishmen to fish and trade in Iceland freely as long as they paid the required tariffs and taxes. It is believed that similar agreements were in place regarding Germans and Dutchmen (Karlsson 2009, 302-303). The relationship between England and Iceland developed from being a commercial one into English fishermen utilizing Icelandic waters. The English fishing industry continued to receive most of its cod from Icelandic waters (Jones (2000, 105-108). 
German dominance of Icelandic trade was increasingly challenged by the Danish crown as the $16^{\text {th }}$ century progressed. Having used the Germans to regain effective control over Iceland from the English (see the next section), the Danish king now wanted to direct the benefits of the Icelandic trade to his own subjects (Karlsson 2009, 309). In the early 1540s the Icelandic governor confiscated 45 German-owned fishing-boats that had been operated by Icelanders in the southwest of the island (Porsteinsson \& Jónsson 1991, 193). The tide had turned against the Germans now that the Danish king was confident that he could rule the island without them. However, as it turned out, the Danes did not have the capacity to provide the necessary ships to take over the Icelandic trade. They therefore chartered German ships for the task (Karlsson 2009, 308-311). Nevertheless, this signalled the beginning of a new era in Icelandic foreign trade. The relatively unregulated and open access of foreigners to Icelandic trade in the $15^{\text {th }}$ and first half of the $16^{\text {th }}$ century was increasingly undermined by the growing grip of the Danish crown in Iceland - eventually leading to the establishment of the Danish trade monopoly.

\section{Political shelter}

The economic developments traced in the previous section took place against the backdrop of Europe's turbulent political landscape in the late Middle Ages which would eventually lead to the emergence of the modern international system in the $17^{\text {th }}$ century (Armstrong 2008). Iceland was a part of the European political world, albeit a peripheral one, and developments on the Continent shaped the course of events on the island. This section traces the political dimension of Iceland's foreign relations and examines whether or not Iceland enjoyed political shelter provided by its neighbours.

The $14^{\text {th }}$ century witnessed radical changes in the political landscape of the Nordic world. Denmark became the leading force in the Kalmar Union (Karlsson 2000, 102) due to its better location regarding the Baltic Sea trade of the Hanseatic League. Also, the Danes outnumbered the Norwegian and Swedish populations combined, and were richer (Porsteinsson \& Grímsdóttir 1989, 217). Iceland remained aloof in these developments. The island was not mentioned in the establishment of the Kalmar Union, since it was regarded as a Norwegian tributary and became part of the union along with the rest of Norway (Dorsteinsson \& Grímsdóttir 1989, 246). Nor do Icelanders seem to have been particularly concerned about the formal position of the country during these developments. The ruling farming elite in Iceland seems to have been primarily concerned with safeguarding its own position and was willing to pledge allegiance to those kings who would uphold their privileges (Porsteinsson \& Grímsdóttir 1989, 246-247). Politically, Iceland thus came under Danish control in the late $14^{\text {th }}$ century and would remain so for more than half a millennium. The reconfiguration of political power in the Nordic world meant that Iceland was more peripheral than before. Instead of being centrally located in Norway's 'North Atlantic Empire' (Karlsson 2000, 100), Iceland was now a remote tributary of Norway, which itself was becoming increasingly marginal.

As discussed in the previous section, King Erik of Pommern sent a letter to Iceland in 1414, forbidding trade with the English. It seems that Icelanders didn't even bother 
to answer the letter for five years and when they did, they more or less refused to obey. In the words of the historians Björn Dorsteinsson and Bergsteinn Jónsson (1991, 154), Iceland had by this time become a "self-governing entity". Still, the king must have been very displeased with such open defiance of his authority and he sent his representatives to Iceland to straighten things out (Dorsteinsson \& Jónsson 1991, 154). A Dane was made governor of Iceland in 1423 and tried to enforce the king's ban on trade with foreigners. This proved difficult and in 1425 the governor was captured by the English and taken against his will to England (Karlsson 2009, 288). Judging by the contemporary account of the incident in New Annal, Icelanders seem to have more or less approved of this. At least his departure "was regretted by few" (quoted in Karlsson 2000, 119).

These events testify to the absence of effective control by the Danish crown in Iceland. Englishmen dominated commerce on the island and met very little resistance except for occasional attempts by the Icelandic elite to influence the course of events. However, this is not to say that there was a significant decrease in the crown's presence on the island in the $15^{\text {th }}$ century from what it had been before 1400 . The Norwegian crown's coercive capabilities in Iceland had been very limited from the beginning and entirely dependent on the king's representatives on the island. However, before the $15^{\text {th }}$ century, this limited presence was quite sufficient for the king's purposes as there was no foreign influence on the island that challenged his rule. It was the arrival of Englishmen in Iceland in the $15^{\text {th }}$ century that radically changed the situation, as Iceland turned from being an easily manageable tributary of the Nordic kingdoms, into being a relative political vacuum targeted by English and German merchants and fishermen.

Nevertheless, as Gunnar Karlsson $(2009,292)$ points out, it should be noted that during the whole period there was a formal ban on English trade in Iceland, which the English crown nominally acknowledged. Even if the trading ban had little effect in practice, there was no attempt by the English crown to take formal control of the island from the Danish king. An important factor here is that the Danish crown controlled the Sound, which was an important trading route for England (Porsteinsson 1970, 109; Gunnarsson 1983; 53). By threatening to halt English ships in the Sound, the Danish crown could force the English crown to negotiate on Icelandic matters and acknowledge Danish authority in Iceland.

Iceland therefore remained formally a part of the Danish kingdom although the crown had almost no coercive capabilities on the island, as is indicated in Figure 2. Indeed, much of the century was characterised by futile attempts by the Danish crown to ban English trade in Iceland. Numerous agreements were made between Denmark and England but seldom enforced (Agnarsdóttir 1993, 164). Iceland was therefore in the ambiguous position of being dominated by English commerce while remaining formally under the Danish crown, due to international developments in Europe. In fact, Björn porsteinsson $(1970,155)$ has suggested that there was, at times, a tacit agreement that the English would confine themselves to commerce in Iceland, while refraining from interfering in politics and matters of the church.

However, this state of affairs collapsed in 1467, with the murder of the Icelandic 


\section{STJÓRNSÝSLA}

Figure 2. The Danish political vacuum in Iceland: Political shelter provided by the King of Denmark from the $15^{\text {th }}$ to the mid- $16^{\text {th }}$ century

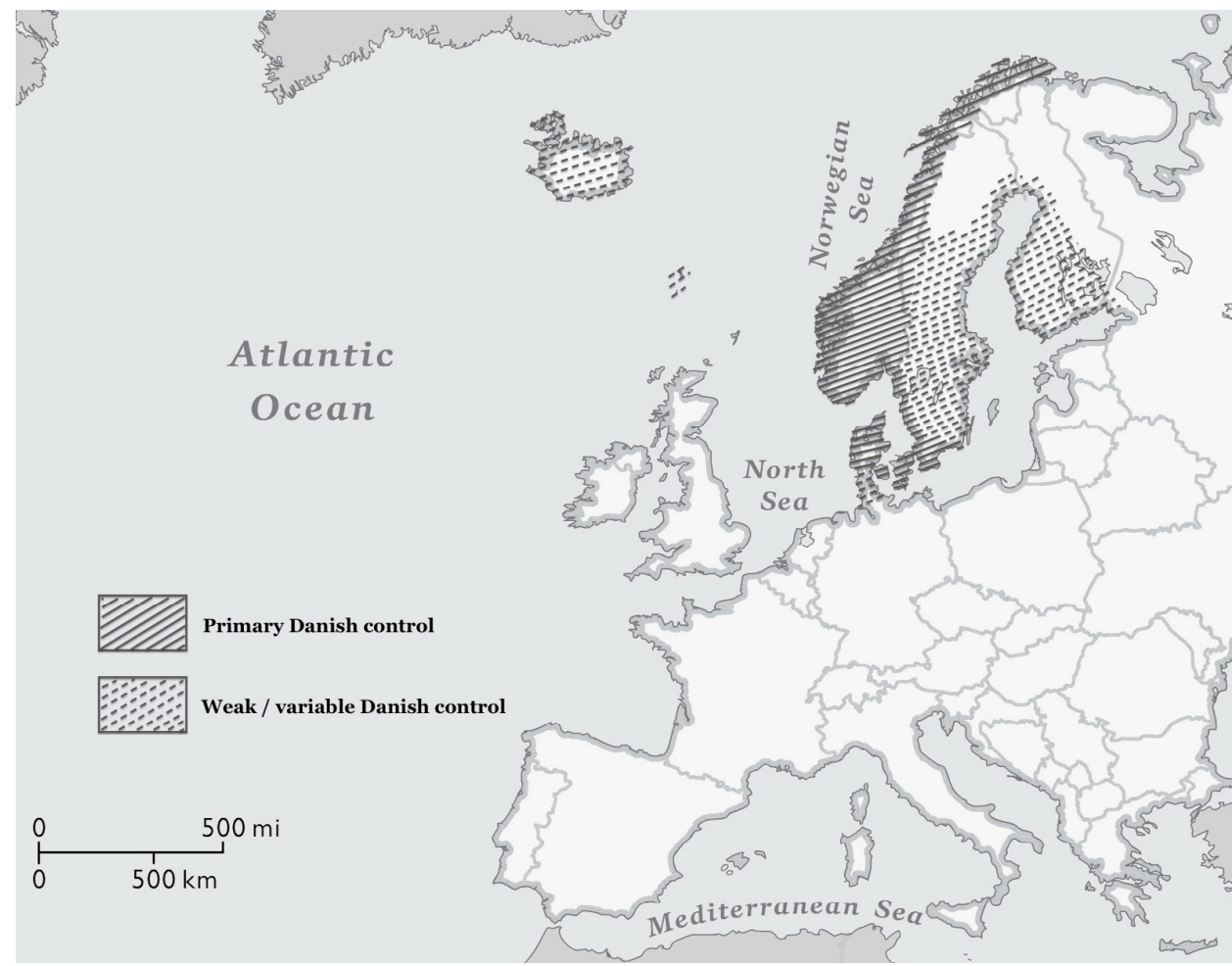

governor, Björn Dorleifsson, at the hands of English merchants. This was considered to be a major event and was widely reported in northern Europe at the time (Dorsteinsson 1970, 207-208). The following year the Danish king closed the Sound and captured seven English ships in revenge (Agnarsdóttir 1993, 166). Hostilities intensified and culminated in a war from 1468 to 1473 , in which the Hanseatic League fought alongside Denmark against England (Karlsson 2000, 121). The participation of Germans in the war would turn out to be an important development for Iceland.

Although German merchants had sailed occasionally to Iceland during the first half of the $15^{\text {th }}$ century, their presence was very limited (Böðvarsson 1976, 35; Porláksson 2001, 271). This changed during the war with England, when the Danish king encouraged the Germans, and especially merchants from Hamburg, to sail to Iceland in order to counter English influence (Agnarsdóttir 1993, 166; Dorsteinsson 1978, 39). This strategy worked well and put an end to English dominance of the Icelandic stockfish trade (Karlsson 2009, 302). As was discussed in the previous section, this was followed by intense competition between English and German merchants for Icelandic harbours, often leading to violent conflict. Between 1484 and 1490, the English crown sent warships 
along with English merchant vessels to Iceland, where they came into conflict with a German sea captain who had been made governor of Iceland (Dorsteinsson 1978, 39-40; Karlsson 2009, 301). The Germans, with the support of the Danish crown, gained the upper hand in the struggle and took control of many of the best harbours (Agnarsdóttir 1993, 166). They worked closely with the Danish authorities and a number of Germans held senior positions in the Icelandic administration (Porsteinsson 1978, 41).

Decisive victory came in 1532, when the Germans took control of Grindavík - one of the most important trading harbours still under English control - in a night-time raid, known as the 'Battle of Grindavík'. The attack was led by the Icelandic bailiff, a German, and cost the lives of about 40 Englishmen (Dorsteinsson \& Jónsson 1991, 175-176; Agnarsdóttir 1993, 166). The Germans later claimed that they had only been acting on behalf of the Danish crown in upholding law and order in the country and the Icelandic authorities ruled that the attack had been fully justified as a response to crimes committed by the English.

The political and economic aspects of Iceland's foreign relations had thus again become closely intertwined. The Danish crown re-established its political muscle in Iceland by allowing - indeed encouraging - the Germans to become economically involved on the island. One could say that the Danish crown outsourced the political project of scaling down English authority in Iceland to German merchants who undertook the political tasks that the Danes had been unable to carry out themselves and, in exchange, reaped the benefits from the Icelandic trade.

However, as discussed in the previous section, the Danish crown eventually stopped sponsoring the Germans and tried to take over the Icelandic trade and administration itself. The Danish crown wanted to transfer the benefits of the Icelandic trade to its own citizens (Karlsson 2000, 126). Frictions between German merchants and the Icelandic administration were already evident in the 1540s, as the confiscation of German fishing boats testifies (Karlsson 2009, 309). The turning point, politically, however, came with the Reformation in the middle of the $16^{\text {th }}$ century (Porláksson 2003). This development is addressed in detail in the next paper (Pórhallsson \& Joensen forthcoming).

Returning to the original question, Iceland was not provided with political shelter from about 1400 to the mid-16 ${ }^{\text {th }}$ century, as is shown in Figure 2. From about 1400 to 1475, the Danish crown was unable to effectively enforce its will in Iceland. The crown's limited coercive capabilities were insufficient to govern the country after the arrival of foreign merchants and fishermen, who easily overwhelmed the island's small administration. Englishmen dominated trade, notwithstanding a formal ban, and more or less behaved as they pleased - sometimes committing acts of violence and pillage. Although the relationship was economically beneficial overall, such transgressions were a constant threat for the islanders. The absence of effective means to enforce law and order were thus a clear manifestation of Iceland's lack of political shelter during the period. The main resistance to English encroachment in Iceland came from Icelanders themselves and not from the Danish crown. The only thing the Danish crown did achieve during this period was to maintain nominal authority in Iceland - due to its control of the Sound 


\section{STJÓRNSÝSLA}

- preventing the island from slipping entirely from its grip and being brought under the English crown in later centuries, according to Björn Porsteinsson $(1976,16)$. Although this was critical for Iceland's future history, it hardly constituted political shelter for the inhabitants of Iceland at the time.

When the Hansa merchants started sailing to Iceland during the war with England, there was a strengthening of political authority exercised in the name of the Danish crown. As previously discussed, the alliance between the Danish crown and the Hansa merchants in Iceland was an alliance of convenience in which the Hansa merchants benefited from Icelandic trade in exchange for restoring the crown's control of the island. However, it seems that the Danes were much more reliant upon the Germans than vice versa until the middle of the $16^{\text {th }}$ century and arguably even longer. Hence, as Figure 2 above indicates, Iceland was still out of reach in terms of effective control by the Danish crown, which depended mostly on the Hansa merchants to exercise its authority (Porsteinsson \& Jónsson 1991, 174-175). Although the power wielded by Germans in Iceland during this period was partly exercised in the name of the Danish crown and meant to restore law and order in Iceland, it must also be understood in the light of the competition between English and German merchants. Iceland was still dominated by foreign powers and the ability of the Danish crown to provide political shelter was very limited.

\section{Societal shelter}

In the 15th century, Icelanders came more often into direct contact with people from different parts of northern Europe. This section will discuss the profound social and cultural consequences of these relations and examine whether these can be regarded as societal shelter according to Rokkan and Urwin's claims of the importance of cultural transactions in terms of the transfer of messages, norms, lifestyles, ideologies, myths and ritual systems.

The increase in foreign trade put strains on the prevailing economic and social structures in the $15^{\text {th }}$ and $16^{\text {th }}$ centuries. The increasing export volume and growing price of Icelandic fish drew people to the south and west coasts of the island where the best fishing grounds were found. It is likely that some embryonic formation of villages took place as people took up permanent residence on the coast, fishing on German-owned boats (Ísleifsdóttir 1997, 117-118). The emerging fishing industry thus competed with the existing agricultural economy for limited labour. A devastating plague in the beginning of the $15^{\text {th }}$ century had already caused labour shortages and would do so again at the end of the century. The social structure of Iceland's agrarian economy came under severe pressure. It is therefore not surprising that the Icelandic farming elite deplored the social impact of the increasing presence of foreigners in Iceland. For example, in 1480, Icelandic landowners wrote a letter to the king of Denmark complaining that foreigners were staying in Iceland all year round and that they are "luring the servants" to come and work for them, leaving the farmers with no one to work on their fields (Böðvarsson 1976, 62-63).

Ten years later, in 1490, the Danish king made an agreement with the English king, 


\section{STJÓRNMÁL \& \\ STJÓRNSÝSLA}

as already stated, allowing Englishmen to fish and trade in Iceland freely. However, when the issue was discussed at the Althingi in the summer, the ruling landowners were clearly concerned about the social implications of the agreement. While they did not challenge the trade agreement as such, they did add several provisions concerning the conduct of foreign merchants in Iceland. Foreigners were forbidden to stay in Iceland during the winter, save in exceptional circumstances, and were then not allowed to have Icelandic servants. Furthermore, they were forbidden to go fishing or to employ Icelanders for this purpose. Finally, the ruling elite decided that all Icelanders were required to be resident on a farm (unless they had a considerable amount of wealth) and were thus forbidden to reside permanently by the sea. This policy was typical for the Icelandic farming elite. They approved of foreign commerce as such, but strongly resisted any transformative influence it might have on the Icelandic society over which they presided (Gunnarsson 1983, 38-42).

However, these attempts to tie the Icelandic population to the farms did not entirely succeed in preventing foreigners from employing Icelanders on their boats. The Germans, in particular, partnered with poor Icelanders, providing them with boats to row on in exchange for 20 per cent of the catch during the fishing season. Outside the fishing season, the Icelanders could use the boats as they pleased. This was an opportunity for the poor and improved their position. Not surprisingly, the elite put an end to this as the Icelandic governor, Otti Stígsson, confiscated the German boats in the 1540s (Böðvarsson 1976, 97-98). Instead, workers had to row for their Icelandic masters for much lower pay. This provides a good example of how foreign influence in Iceland had a beneficial effect for the common man but was deliberately suppressed by the Icelandic elite in order to safeguard its position of power in the existing social structure.

Another important social development during the English and German periods was the diversification of products imported to Iceland. Moreover, the volume of products imported to Iceland multiplied during this period (Hjaltalín 2004, 217). The expansion of trade, together with the relative increase in price for Icelandic products, offered many Icelanders the opportunity to purchase a variety of products that had not been imported before. Common European goods became available to a much larger group than before. For instance, the English imported various types of cloth, including a multicoloured fabric produced specifically for the Icelandic market, as well as boots, headwear, laces, gloves, belts and leather shoes - presumably having a considerable influence on people's day-to-day apparel. Cooking pots first became a widespread household good in the $15^{\text {th }}$ century. Also, diversity in food increased as the English, and later Germans, imported large quantities of beer and wine, salt and pepper, malt, wheat, sugar and honey. Furthermore, the Church relied on English imports, e.g. buying altarpieces, rosaries and wax to make candles. Finally, mention should be made of the import of wood, nails, tar, oars, fishing lines and fishing hooks - necessary for building and operating fishing boats (Porsteinsson 1980, 251-252). These diverse products, many of them new to Icelanders and imported in hitherto unparalleled quantities, must have had a discernible effect for the better on people's daily lives. They provided Icelanders with useful household 


\section{STJÓRNSÝSLA}

goods, diversified their diet and brought current European trends to the island, whether in clothing or religious ideology. These are clearly 'cultural transactions' as Rokkan and Urwin define them, and in this sense Icelanders enjoyed decisive societal shelter from their relations with the English and the Germans, who kept them in touch with the rest of Europe, as is demonstrated in Figure 3. They expanded Iceland's external contacts and brought its people associated benefits of many kinds.

The growing power of the pope over the Icelandic church brought it, and society at large, into closer contact with the European Continent. Around the end of the $14^{\text {th }}$ century, the pope started to choose Icelandic bishops himself, often in consultation with the Danish crown, instead of their being elected by church institutions in Norway as had been the case since the middle of the $13^{\text {th }}$ century. This development was part of a broader trend within the Catholic church at the time. In the Scandinavian world this meant that the pope often worked with the secular authorities while side-lining local church institutions (Porsteinsson \& Grímsdóttir 1990, 34-40). The Norwegian church had traditionally only elected Icelanders and Norwegians to serve as bishops in Iceland.

Figure 3. Iceland's societal shelter: Cultural transactions with the English and Germans, the Christian world and Danish rulers from the $15^{\text {th }}$ to the mid- $16^{\text {th }}$ century.

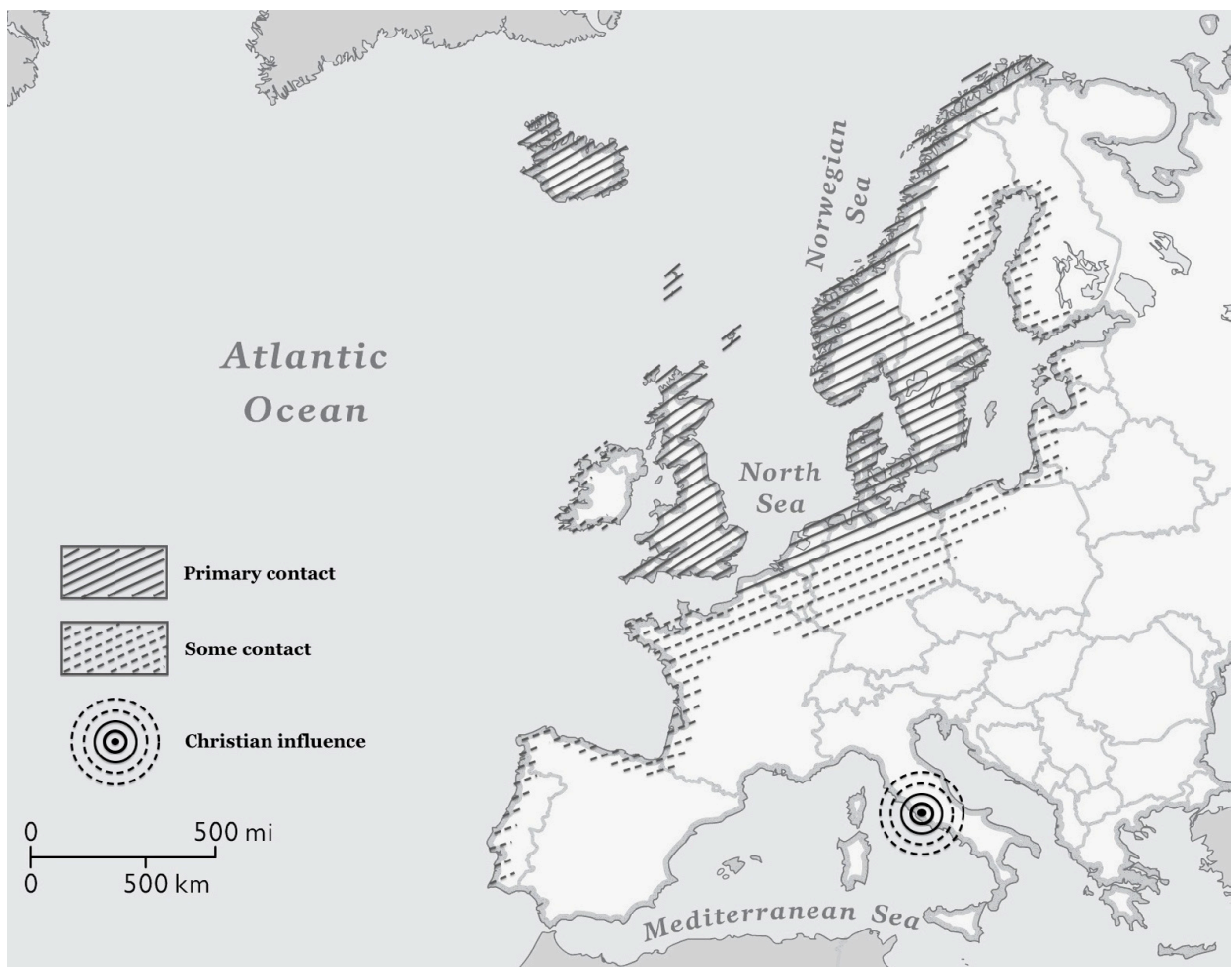


However, during the $15^{\text {th }}$ century, the Icelandic bishoprics were occupied by men of different nationalities including Danes, Englishmen and even a Dutchman (Jóhannesson $1958,115)$. These bishops did not come to Iceland alone. They were usually accompanied by a number of their own countrymen, both priests and laymen, who had various roles in Iceland (Guðmundsson 2000, 124-125, 246; Carus-Wilson 1954, 123-124). The bishoprics' overseas contacts with the Catholic church were supplemented with considerable external trade (Carus-Wilson 1954, 123-124; Childs 1995, 14-19). Considering that the church was the principal source of information and education in Iceland at the time, it is clear that this sudden influx of foreign clergy and their entourages must have had considerable social and cultural influence. The tumultuous religious and ideological developments on the Continent were now transmitted directly to Iceland, instead of being filtered through the Nordic world as before. For example, a Dutch bishop, who served in Iceland from 1437 to 1447, was strongly influenced by the new religious movement Devotio moderna and his conduct in Iceland is said to reflect the movement's ideology. It is unclear whether the bishop actively sought to promote the religious movement in Iceland, but archaeological finds in Viðey from around the same time suggest that monks there copied Dutch religious poems (Guðmundsson 2000, 124-125). Catholic religious poetry was much cultivated in Iceland at the time and was strongly influenced by similar poetry in Europe. Indeed, it is said to have reflected a "surprisingly good knowledge of literary developments in Europe” (Ólason et al. 2006, 220, 286, 377). Accordingly, Icelandic literature followed Continental European literary trends. Moreover, Icelanders felt so closely connected to the Continent though 'the international Church' that prominent people who got into trouble with the local church authorities were known to send letters directly to the pope in the hope that he would resolve their problems - which, indeed, he sometimes did (Guðmundsson 2000, 132-133). Figure 3 shows that Icelanders were part of the common Catholic world.

Another interesting example of foreign influence and, in fact, societal shelter, through the Catholic church is the operation of monasteries in Iceland before the Reformation (Guðmundsson 2000, 246). The recent excavation of Skriðuklaustur, an Icelandic monastery in operation from the late $15^{\text {th }}$ century to the Reformation, confirms that Icelandic monasteries were similar to other monasteries in Europe at the time. The building was structured according to a general European model and the monastery's purpose was the same as that of others in Europe (Kristjánsdóttir 2012, 60, 68). Indeed, Steinunn Kristjánsdóttir emphasises that the operation of Icelandic monasteries must be understood in an international context. The monasteries were "part of an international institutional network based on the doctrine of the Catholic Church and connected Iceland with other countries." (Kristjánsdóttir 2012, 246-247, 328, 344-345). Testimony to the international nature of Icelandic monasteries is provided by the religious artefacts found at Skriðusklaustur. Among the finds are artefacts from both the Netherlands and France. Steinunn Kristjánsdóttir (2012, 99-100) speculates that these artefacts are related to an Icelandic bishop who had studied in France and possibly remained in contact with his colleagues after he became bishop in Skálholt. 


\section{STJÓRNSÝSLA}

Importantly, findings at Skriðuklaustur also show that Icelandic monasteries, like their counterparts elsewhere in Europe, served an important social function in medieval Icelandic society. They were a "sanctuary for the sick and elderly, as well as being a centre for Christian education and study” (Kristjánsdóttir 2012, 195-247, 329). The excavation revealed that many of the 259 people who were buried there in the 60 years during which the monastery was operated had clearly suffered from various forms of illnesses and had been cared for at the monastery until their death.

The monasteries in Iceland, along with the bishoprics, were the largest institutions on the island, and at the time of the Reformation, Icelandic monasteries owned around 15 per cent of all landholdings in the country (Dorláksson 2003, 99). It is therefore clear that the operation of Catholic monasteries in Iceland was a form of societal shelter. They were driven by the international ideology of the Catholic church, serving as a kind of hospital and sanctuary for those who were in a vulnerable position in society (Kristjánsdóttir 2008, 2012-214).

Furthermore, Icelanders themselves also played an important role as bearers of foreign influence into the country. With the increased maritime contact in the $15^{\text {th }}$ and the early $16^{\text {th }}$ centuries, more Icelanders could travel abroad. A number of Icelanders went to live and work both in England and Germany, some of them never to return, while others came back and played important roles in Icelandic society, often serving as mediators in the dealings between foreigners and locals. For example, in 1443 there were two Icelandic householders in Hull and in 1465-66 two householders and nine other Icelanders (Childs 1995, 13) and in 1486 there were 49 Icelanders in Bristol alone (Dorsteinsson 1969, 54). In the first half of the $16^{\text {th }}$ century, Hamburg is said to have been Iceland's "gateway to the outside world" and Icelander's usually passed through the city on their way to meet the Danish king (Porláksson 2003, 38-39). Icelanders are known to have studied in German universities and, unsurprisingly, this was where many of the protagonists of the Reformation in Iceland took to Lutheranism during their studies (Ólason et al. 2006, 381-386). For instance, the first Lutheran bishop in Iceland studied in Hamburg, where he encountered Protestantism. Interestingly, in 1540, one of Iceland's two episcopal sees, Skálholt, became Lutheran only 3-4 years after the Danish King implemented the Protestant Reformation in Denmark and Norway. However, it took another decade for the whole country to submit formally to Lutheranism. These developments will be analysed in greater detail in the next paper (Dórhallsson \& Joensen forthcoming).

Finally, it should be noted that Iceland's status as a Christian island with cultural ties to the rest of Europe may have provided its inhabitants with shelter in their dealings with foreigners. In the absence of effective law enforcement, these cultural ties served as ethical constraints on the conduct of foreigners in Iceland. One only has to think of how Europeans treated the peoples of the non-European world in the colonial era to see how much more easily people can brutalise each other in the absence of cultural affinities and similarities. Arguably, Icelanders were spared such treatment because they belonged to the same cultural world as the foreigners that washed up on their shores. 
To summarise: interestingly, the formal external authority in Iceland was not the main provider of societal shelter. Multiple and wider contacts provided Icelanders with a broader social cover in the late Middle Ages compared with the preceding era. Icelanders followed developments in Western Europe closely: Anglo-German influence was particularly noticeable; the international role of the Catholic church was clearly felt; Danish influence was apparent as Iceland was formally under Danish rule and new Dutch and other Continental influences can be traced on the geographically remote island. Cultural transactions between Iceland and these areas had a profound effect on Icelanders' lifestyles, norms and ritual systems. Iceland was part of the western European community. German and English contact provided the islanders with important societal shelter and kept the population, at large, in contact with its neighbours.

\section{Conclusion}

Around the turn of the $14^{\text {th }}$ century, a number of converging factors put Iceland on the larger European map. Advancements in sailing technique and the emergence of larger vessels made the export of Icelandic stockfish commercially viable, and before long the island's rich fishing grounds drew fishermen and merchants from different parts of northern Europe - primarily England and Germany. This development was facilitated by the lack of interest and capacity of the Danish rulers to exercise their authority on the island. The result for Iceland was a complex mix of limited external rule and wider European influence in terms of increased trade and cultural communication. These relations provided Icelanders with important economic and societal shelter. At the same time, they were not provided with political shelter. The shelter that Icelanders had enjoyed from Norwegian sea power (see the first paper by Baldur Pórhallsson 2012) faded out with its decline and the establishment of the Kalmar Union. The focus of Danish interest lay to the south and east of Copenhagen, and Iceland no longer enjoyed a widereaching and decisive shelter provided by a Scandinavian power.

Nevertheless, the island, despite its remoteness, was part of the power struggle between competing European powers. Occasionally, events in Iceland led to direct and indirect conflicts, particularly between the kings of England and Denmark. German Hansa merchants became the dominant economic actors in Iceland as a result of their alliance with the Danish crown in a war against England. Hansa merchants benefited from the Icelandic trade and, in exchange, slowly restored the Danish crown's control of the island. Thus, competition between English and German merchants in Iceland, and the ambiguous role of the Danish crown, closely followed the patterns of alignment and competition between these actors in Europe at the time. Iceland had become integrated into the international system of the times, being influenced by developments in Europe and, occasionally, influencing events there. Importantly, for future developments in Iceland, the Danish king maintained his nominal authority on the island due to his control of the Sound.

The case of Iceland in the late Medieval Period has three implications for our theoretical framework, the shelter theory, and, in general, small-state studies. Firstly, there 


\section{STJÓRNSÝSLA}

might be a trade-off between the benefits of strict political cover by a single external actor, and the economic and societal opportunities accompanied by a lack of political affiliations. The Danish political vacuum provided Icelanders with important economic opportunities and social engagements with the wider world. The economic cost to them would have been severe, had the Danish king succeeded in banning or restricting further trade with the island. Hence, firm political shelter may not be a necessity in order for an entity and its inhabitants to enjoy external economic and social comfort. On the other hand, the absence of a political shield took its toll (according to the thesis) in terms of continued domestic clashes between Icelanders themselves, on the one hand, and between them and 'outsiders' on the other. Iceland was 'a battlefield' of competing European merchants and fishermen. The Danish authorities on the island lacked sufficient resources and political will (from Copenhagen) to exercise their formal powers. As a consequence, they were not able to uphold law and order. The shelter theory needs to analyse the potential freedom and associated benefits and costs that an entity may enjoy in the case of political vacuum. Moreover, the shelter theory needs to draw lessons from the various examples regarding different types of shelter providers that states may have in the form of a number of external actors; the formal external authority may not actually be the shelter provider. This was at least the case of Iceland in the late Medieval period.

Secondly, foreigners' activities in and around the island seem not only to have provided the rich landowners with increased wealth. Foreign contacts provided at least part of the general public with economic and societal shelter in terms of new employment opportunities and other benefits such as new household equipment and other imported products. Also, the 'international' Catholic doctrine meant that monasteries provided a part of the public with care and education. The transfer of messages from abroad became more common and Icelanders' lifestyles became more like those in the neighbouring states. Furthermore, new evidence which confirm that the Icelandic church's ritual systems replicated the developments in the Catholic faith show that the remote island was not out of touch with 'the rest of the world'. Icelanders' norms are likely to have become more similar to the common trend in England and on the Continent. Accordingly, this strengthens our previous findings on the importance of societal communication with the outside world. The shelter theory and small-state studies in general need to take notice of the societal shield that external relations may bring small entities. The findings confirm Rokkan and Urwin's claims that cultural transfers in the form of messages, norms, lifestyles, ideologies, myths and ritual systems are important in constructing centre-periphery relations.

Thirdly, in accordance with the point above, foreign activities in Iceland seem to have placed considerable constraints on the prevailing economic and social structures. Importantly, at times, the ruling farming class somewhat lost its grip on part of the public, or was afraid of losing it. The elite would only approve increased foreign contact if its economic interests and dominance over Icelandic society were not threatened. Thus, the elite would place severe constraints on the foreigners' activities on the island and 


\section{STJÓRNMÁL \& \\ STJÓRNSÝSLA}

the islanders' relations with them in order to maintain its control. This was to become a common practice of the landowning elite. Its interests were at stake. Accordingly, the shelter theory needs to take into account differing impacts that external relations may have on the ruling class, on the one hand, and the general public on the other. Moreover, external affairs may have profound political, economic and societal consequences and alter the prevailing structures. Domestic responses to such challenges may be decisive in determining whether or not a potential external shelter comes into being and who are the winners and losers when societies undergo a sea change such as when coming under protection of a new entity.

The absence of a protecting political power is striking and had considerable implications in our era. Indeed, much of Icelandic politics has revolved around the question of how to structure Iceland's foreign relations and allocate associated benefits from the relations. The shelter theory needs to study in depth the domestic political effects of an external political shelter, on the one hand, and the lack of a protecting power on the other. The Icelandic domestic elite welcomed increased foreign relations and external shelter but only as long as it could control their implications. What consequences does the non-availability of political shelter have on domestic power struggles? Who is most likely to gain from an external power vacuum? Is a new political external shelter likely to strengthen or weaken the prevailing domestic ruling class?

Finally, the Danish king slowly but steadily strengthened his authority in Iceland in the latter part of the period under study. In the beginning, the Germans provided essential assistance and, in fact, the king continued to rely upon them until the middle of the $16^{\text {th }}$ century. Later, the Danes themselves took control. This paved the way for stronger central authority and the establishment of the Danish trade monopoly. A radical change in Iceland's external affairs followed; this will be the subject of the next paper in this series.

\section{Notes}

1 The authors would like to thank the following scholars for valuable comments that helped to improve the paper: Alyson J.K. Bailes, Gunnar Karlsson, Helgi Skúli Kjartansson, Jeffrey Cosser, Jón Karl Helgason, Stefanía Óskarsdóttir, Sverrir Jakobsson and Tómas Joensen.

2 The following period of Danish Rule will be treated in two papers (from the Reformation to the end of the Napoleonic era and from 1814 to 1944). This will be followed by examinations of 'the American Period' and 'the new European Period'.

\section{References}

Agnarsdóttir, A. (1993). "Ísland á bresku áhrifasvæði fram að síðari heimsstyrjöld", in M. Snædal and T. Sigurðardóttir (eds.) Frandafundur: Fyrirlestrar frá islensk-fareyskri rádstefnu i Reykjavík 20.-21. ágúst 1992. Reykjavík: Háskólaútgáfan, 162-178.

Agnarsdóttir, A. (2000). "Ísland og umheimurinn 1580-1630", Skirnir 181 (vor): 413-430.

Armstrong, D. (2008). "The evolution of international society" in J. Baylis, S. Smith and P. Owens (eds.) The Globalization of World Politics. $4^{\text {th }}$ edition. Oxford: Oxford University Press, 36-52. 


\section{STJÓRNSÝSLA}

Bailes, A.J.K. \& Thorhallsson, B. (2013). "Instrumentalising the European Union in Small State Strategies", Journal of European Integration 35 (2): 99-115.

Böðvarsson, J.E. (1976). Dýsk-iślenzk verslunarsamskipti á 15. og 16. öld. (unpublished master's thesis at the University of Iceland).

Carus-Wilson, E.M. (1954). Medieval Merchant Venturers: Collected studies. London: Methuen \& Co. Ltd.

Childs, W. (1995). "England's Icelandic Trade in the Fifteenth Century: The Role of the Port of Hull", in P. Holm, O. Janzen and J. Thór (eds.) Northern Seas Yearbook 1995: Association for the History of the Northern Seas. Esbjerg: Fiskeri- og Søfartsmuseet, 11-31.

Gade, J.A. (1951). The Hanseatic Control of Norwegian Commerce During the Late Middle Ages. Leiden: Brill.

Guðmundsson, G.F. (2000). "Íslenskt samfélag og Rómakirkja”, in H. Hugason (ed.) Kristni á Íslandi, II. bindi. Reykjavík: Alpingi.

Gunnarsson, G. (1983). Monopoly Trade and Economic Stagnation: Studies in the Foreign Trade of Iceland 1602 1787. Lund: Ekonomisk-historiska föreningen.

Hjaltalín, P. (2004). "Vöruframboð og verslunartengsl” in Á. Björnsson and H. Róbertsdóttir (eds.) Hlutavelta timans. Reykjavík: National Museum of Iceland, 214-223.

Ísleifsdóttir, V.A. (1997). Siðbreytingin á Íslandi 1537-1565: Byltingin að ofan. Reykjavík: Hið íslenska bókmenntafélag.

Jakobsson, S. (2005). Við og veröldin: Heimsmynd Íslendinga 1100-1400. Reykjavík: Háskólaútgáfan.

Jones, E. (2000). "England's Icelandic Fishery in the Early Modern Period", in D.J. Starkey, C. Reid and N. Ashcroft (eds.) England's Sea Fisheries: The Commercial Sea Fisheries of England and Wales since 1300. London: Chatham Publishing, 105-110.

Jóhannesson, J. (1958). Íslendinga saga II. Fyrirlestrar og ritgerdir um tímabilid 1262-1550. Reykjavík: Almenna bókafélagið.

Karlsson, G. (2000). Iceland's 1100 Years: The History of a Marginal Society. London: Hurst \& Company.

Karlsson, G. (2009). Lifsbjörg Íslendinga frá 10. öld til 16. aldar. Reykjavík: Háskólaútgáfan.

Katzenstein, P.J. (1985). Small States in World Markets: Industrial Policy in Europe. Ithaca and London: Cornell University Press.

Katzenstein, P.J. (1997). “The Smaller European States, Germany and Europe”, in P. J. Katzenstein (ed.) Tamed Power: Germany in Europe. Ithaca and London: Cornell University Press.

Kjartansson, H.S. (1996). “Forn-Íslendingar: iðnaðarpjóð”, Visbending 14 (48): 21-23.

Kristjánsdóttir, S. (2008). "Skriðuklaustur monastary: Medical Centre of Medieval East Iceland?”, Acta Archaeologica 79 (1): 208-215.

Kristjánsdóttir, S. (2012). Sagan af klaustrinu á Skriðu. Reykjavík: Sögufélag.

Linklater, A. (2008). "Globalization and the transformation of political community", in J. Baylis, S. Smith and P. Owens (eds.) The Globalization of World Politics. $4^{\text {th }}$ edition. Oxford: Oxford University Press, 542-558.

Linklater, A. (2009). "Historical Sociology", in S. Burchill et al. (eds.) Theories of International Relations. $4^{\text {th }}$ edition. Hampshire: Palgrave Macmillan, 136-158.

Ólason, V. (ed.), Guðmundsson, B., Tómasson, S., Tulinius, T.H. (2006). Íslenske bókmenntasaga II. $2^{\text {nd }}$ edition. Reykjavík: Mál og menning.

Rokkan, S. \& Urwin, D.W. (1983). Economy, Territory, Identity: Politics of West European Peripheries. London: Sage.

Rothstein, R.L. (1968). Alliances and Small Powers. New York and London: Columbia University Press.

Thorhallsson, B. (2011). "Domestic Buffer Versus External Shelter: Viability of Small States in the New Globalised Economy”, European Political Science (10): 324-336.

Tilly, C. (1990). Coercion, Capital, and European States, AD 990-1990. Oxford: Basil Blackwell.

Vital, D. (1967). The Inequality of States: A Study of the Small Power in International Relations. Oxford: Clarendon Press. 
Dorláksson, H. (1991). Vadmál og verđlag: Vadmál i utanríkisvidskiptum og búskap Íslendinga á 13. og 14. öld. Reykjavík.

porláksson, H. (1999). Sjórán og siglingar: Ensk-islensk samskipti 1580-1630. Reykjavík: Mál og menning.

porláksson, H. (2001). "Íslensk skreið skákar norskri”, in G. Gíslason (ed.) Lindala: Sigurour Lindal sjötugur 2. júlí 2001. Reykjavík: Hið íslenska bókmenntafélag, 265-293.

porláksson, H. (2003). "Frá kirkjuvaldi til ríkisvalds", in S. Líndal (ed.) Saga Íslands VI. Reykjavík: Hið íslenzka bókmenntafélag, 1-408.

porsteinsson, B. (1964). "Pættir úr verzlunarsögu: nokkur atriði úr norskri verzlunarsögu fyrir 1350", Saga IV, 3-52.

porsteinsson, B. (1965). "Íslands- og Grænlandssiglingar Englendinga á 15. öld og fundur NorðurAmeríku”, Saga V, 3-72.

porsteinsson, B. (1969). Enskear heimildir um sögu Íslendinga á 15. Og 16. öld. Reykjavík: Hið íslenzka bókmenntafélag.

Porsteinsson, B. (1970). Enskea öldin i sögu Íslendinga. Reykjavík: Mál og menning.

porsteinsson, B. (1976). Tíu porskastrí 1415-1976. Reykjavík: Sögufélagið.

porsteinsson, B. (1978). Á fornum slódum og nýjum. Reykjavík: Sögufélag.

porsteinsson, B. (1980). Íslensk miðaldasaga. 2. útg. Reykjavík: Sögufélag.

Porsteinsson, B. \& Grímsdóttir, G.Á. (1989). "Norska öldin með viðaukum eftir Sigurð Líndal”, in S. Líndal (ed.) Saga Íslands IV. Reykjavík: Hið íslenzka bókmenntafélag, 59-258.

Porsteinsson, B. \& Grímsdóttir, G.Á. (1990). "Enska öldin með viðaukum eftir Sigurð Líndal”, in S. Líndal (ed.) Saga Íslands V. Reykjavík: Hið íslenzka bókmenntafélag, 1-216.

porsteinsson, B. \& Jónsson, B. (1991). Íslandssaga til okkear daga. Reykjavík: Sögufélag.

pórhallsson(Thorhallsson), B. (2012). "Iceland's external affairs in the Middle Ages: The shelter of Norwegian sea power”, Stjórnmál og stjórnsísla 8 (1): 5-37.

Pórhallsson(Thorhallsson), B. \& Joensen, T. (forthcoming) Iceland's External Affairs from the Reformation to the end of the Napoleon era. 